MONIKA MADEJ, Ph. $\mathrm{D}^{1}$

(Corresponding Author)

E-mail: mmadej@tu.kielce.pl

MICHAŁ PAJAKK, Ph.D. ${ }^{2}$

E-mail: m.pajak.poczta@interia.pl

${ }^{1}$ Faculty of Mechatronics and Mechanical Engineering

Kielce University of Technology

Al. 1000-lecia P.P. 7 25-314 Kielce, Poland

2 Provincial Headquarters of State Fire Service in Kielce

ul. Sandomierska 81, 25-324 Kielce, Poland
Safety and Security in Traffic

Preliminary Communication

Submitted: 28 Oct. 2018

Accepted: 27 June 2019

\title{
ROAD TRANSPORT OF DANGEROUS GOODS IN POLAND - RISK ANALYSIS
}

\begin{abstract}
The paper presents the methodology for the risk anal$y$ sis of the road transport of dangerous goods. The risk analysis includes the societal risk for communities living or staying within a radius of six kilometres from all national roads in Poland. The GIS software was employed to make this analysis. The prepared matrix has included the product of the likelihood of a road accident involving explosive dangerous goods and the consequences for communities living in the abovementioned area. The likelihood analysis was developed for explosive and toxic dangerous goods. The consequence analysis was based on the population density, according to which a respective number of people was assigned to each building, depending on the time of day (daytime, nighttime). Each stage of the analysis was presented in the form of a map. In total, two variants of the likelihood analysis, four variants of the consequence analysis and four variants of risk analysis have been developed. All analyses have been developed for the entire country.
\end{abstract}

\section{KEY WORDS}

transport; dangerous goods; risk analysis; population density;

\section{INTRODUCTION}

Dangerous goods transported by road are a real threat to the society. In the past, the events involving dangerous goods caused many fatalities. Population density is an important determinant of the risk level connected with an accident involving dangerous goods. Population distribution is also significant due to potential use of lorries carrying dangerous goods by terrorists. The following definitions are used in this paper: hazard - the possibility of an adverse event (e.g. a road accident involving dangerous goods), that may cause disturbances in the analysed system or losses [1]; risk - the product of the hazard-trigger event likelihood (a hazard is considered as a road accident involving dangerous goods) and the resulting losses [1]; risk analysis - estimation of the likelihood, the con- sequence and the risk level [2, 3]; societal risk - likelihood of a certain number of people in a given area being exposed to the negative effects of an adverse event [4].

In order to analyse the risk associated with the road transport of dangerous goods, the societal risk was used. This risk concerns people who live or work near the national roads. For the purposes of the methodology, all national roads are divided into sections up to one kilometre. The risk analysis was developed individually for each of the aforementioned sections, covering the area with a radius of up to six kilometres. The analysis was based on the matrix representing the product of the likelihood analysis of an accident in road transport involving dangerous goods and the consequence of the above event on the communities living or working near the national roads.

The likelihood analysis was developed for two variants related to the type of dangerous goods and they were divided into explosive dangerous goods and toxic dangerous goods. In this paper, the explosive dangerous goods are understood as dangerous goods included into classes: 1, 2 (flammable gases only), 3, 5.1 and 5.2; whereas toxic dangerous goods include classes: 2 (poisonous gases only), 6.1 and 8 . According to Eurostat 2016 figures, explosive dangerous goods accounted for $67 \%$ of all the transported dangerous goods, while toxic dangerous goods accounted for $14 \%$ of all transports. Other transports (19\%) of dangerous goods are included into classes 7 and 9 [5].

The consequence analysis was developed in relation to the losses related to casualties. The material and environmental losses were not analysed. The consequence analysis was based on the population density methodology, according to which the individual average population was assigned to each building at night and day.

The consequence analysis did not take into account road traffic conditions, due to the lack of reliable data registers for individual sections of national roads. 
Currently, traffic data are available for the selected points on national roads. In the next stage of the study, they are expected to be used in the analysis of individual sections of national roads.

As result of the product of two variants of the likelihood analysis and four variants of the consequence analysis, four variants of the risk analysis were developed.

Most of the scientific research on the risk analysis takes mainly into account the human-related factor (driver behaviour) [6, 7], weather conditions [8] and the intensity of road traffic $[8,9]$. In this work, data on road infrastructure, accident distribution and population density were taken into account. All the abovementioned data have a spatial reference and are complete for the entire territory of Poland.

\section{METHODOLOGY}

\subsection{Likelihood analysis of an accident}

The causes of accidents in road transport can be classified into the following groups: human, vehicle, road, traffic, weather conditions and the surroundings $[8,10]$. Because of the availability of spatial data for the whole country, the likelihood analysis was based mainly on the likelihood assessment of road accidents which are related to: road (pavement condition, whether the road is partially or non-grade-separated, or fully grade-separated), human (the availability of parking areas for vehicles carrying dangerous goods - rest areas) and traffic (the spatial distribution of accidents involving dangerous goods in the past).

The likelihood analysis does not take into account weather conditions due to the lack of availability of the abovementioned data for individual sections of national roads.

Two variants of the likelihood analysis for dangerous goods were developed and these are:

- related to explosion;

- related to the emission of toxic or poisonous vapours.
The likelihood value was assigned to each section of the national road, up to one kilometre in length, according to the following formulas:

$$
\begin{aligned}
& P_{W}=0.35 W_{W}+0.45 K+0.1 N+0.1 A \\
& P_{T}=0.35 W_{T}+0.45 K+0.1 N+0.1 A
\end{aligned}
$$

where:

$W_{W}$-the national-road layer divided into sections with an assigned value defining the frequency of accidents involving tanker lorries carrying explosive dangerous goods; the values are on a scale of $0 ; 0.25 ; 0.5 ; 0.75 ; 1$;

$W_{T}$-the national-road layer divided into sections with an assigned value defining the frequency of accidents involving tanker lorries or IBC carrying toxic dangerous goods; the values are on a scale of $0 ; 0.25 ; 0.5 ; 0.75 ; 1$;

$K \quad$-the national-road layer divided into sections with an assigned value defining whether the road is partially or non-grade-separated, or fully grade-separated; the values are on a scale of $0 ; 1$;

$N$-the national-road layer divided into sections with an assigned value defining road pavement quality; the values are on a scale of $0 ; 0.2$; $0.5 ; 1$;

$A$-the national-road layer divided into sections with the assigned availability of parking areas for vehicles carrying dangerous goods; the values are on a scale of $0 ; 0.5 ; 1$.

The weights of individual components of the formula were calculated based on the literature, study findings and expert knowledge (Table 1). It should also be noted that this is the beginning of work on the methodology.

In order to determine the likelihood analysis, GIS layers that contain information necessary to calculate Formulas 1 and 2 were employed.

Table 1 - Weights for the likelihood formula

\begin{tabular}{||l|l|l|l|l||}
\hline $\begin{array}{c}\text { Group of } \\
\text { accident } \\
\text { causes }\end{array}$ & \multicolumn{1}{|c|}{$\begin{array}{c}\text { Road } \\
(0.55)\end{array}$} & \multicolumn{1}{|c|}{$\begin{array}{l}\text { Traffic } \\
(0.45)\end{array}$} & \multicolumn{1}{c|}{$\begin{array}{l}\text { Driver } \\
(0.1)\end{array}$} \\
\hline \hline $\begin{array}{l}\text { Weight - } \\
\text { factor of } \\
\text { accident }\end{array}$ & $\begin{array}{l}\text { K: 0.45 - partially or } \\
\text { non-grade-separated roads } \\
\text { and fully grade-separated } \\
\text { roads }\end{array}$ & $\begin{array}{l}\text { N: 0.1 - road } \\
\text { pavement condition }\end{array}$ & $\begin{array}{l}\text { W: } 0.45 \text { - accident } \\
\text { occurrence in the } \\
\text { past }\end{array}$ & $\begin{array}{l}\text { A: 0.1 - availability of rest } \\
\text { areas }\end{array}$ \\
\hline $\begin{array}{l}\text { Justification } \\
\text { of the } \\
\text { assigned } \\
\text { weight }\end{array}$ & $\begin{array}{l}\text { 65\% of accidents on national } \\
\text { roads involving dangerous } \\
\text { goods took place on } \\
\text { non-grade-separated national } \\
\text { roads. It results from the fact } \\
\text { that non-grade-separated } \\
\text { roads constitute the majority } \\
\text { of all national roads. }\end{array}$ & $\begin{array}{l}\text { 1. Improper infra- } \\
\text { structure has an } \\
\text { indirect or direct } \\
\text { impact on 30\% of all } \\
\text { accidents [11]. } \\
\text { 2. Road pavement } \\
\text { condition is a minor } \\
\text { factor in accidents in } \\
\text { question [12]. }\end{array}$ & $\begin{array}{l}\text { According to the } \\
\text { literature the } \\
\text { intensity of traffic is } \\
\text { proportional to the } \\
\text { frequency of } \\
\text { accidents [13]. This } \\
\text { factor has got high } \\
\text { significance. }\end{array}$ & $\begin{array}{l}\text { Due to the fact that the } \\
\text { driver's behaviour is a key } \\
\text { factor in the occurrence of } \\
\text { an accident and involves } \\
\text { many aspects [7], parking } \\
\text { space availability was } \\
\text { identified as one of the } \\
\text { many aforementioned } \\
\text { factors. }\end{array}$ \\
\hline
\end{tabular}


Data used to develop the accident layer come from the resources of Geodesic and Cartographic Documentation Centre, General Directorate for National Roads and Motorways and National Headquarters of the State Fire Service and the preliminary studies [14].

Actions involving tanker lorries (explosive and toxic dangerous goods) and IBC containers (toxic dangerous goods). The above events presented the greatest hazard due to the amount of carried dangerous goods per transport unit.

In order to develop the accident layer for each section of national roads with length of up to one kilometre, an area with a radius of $15 \mathrm{~km}$ was analysed in terms of their number. Based on the calculations, a five-point scale from 0 to 1 was developed, where:

- 0 means sections where no accidents occurred in the past;

- 1 means sections with the largest number of accidents [14].

The GIS layer connected with fully/partly grade-separated and non-grade-separated national roads was developed using two-point scale, according to which the value of 0 was assigned to fully grade-separated sections and the value of 1 was assigned to partially or non-grade separated sections [15].

The GIS layer related to road pavement condition adopted the scale, according to which:

- road sections with a very good pavement condition were assigned the value 0 ;

- road sections with a tolerable pavement condition were assigned the value 0.2 ;

- road sections with a poor pavement condition were assigned the value 0.5 ;

- road sections with a very poor pavement condition were assigned the value 1 [14].

Subsequently, the GIS layer related to the availability of parking areas intended for vehicles carrying dangerous goods was established. Each national road section with the length of up to one kilometre was assigned by the availability of parking areas.

It was calculated by taking into account the distance of a given road section from the nearest parking areas. A three-point scale was adopted according to which:

- the value of 0 was assigned to road sections for which parking areas are available within a radius of $15 \mathrm{~km}$;

- the value of 0.5 was assigned to road sections for which parking areas are available within a radius of 15 to $60 \mathrm{~km}$;

- the value of 1 was assigned to the remaining road sections $[11,14]$.

\subsection{Consequence analysis of an accident}

The consequence analysis was developed for the purpose of assessing the societal risk for people living or working within a radius of up to six kilometres from national roads. It was developed taking into account the population density. It should also be emphasised that the consequence analysis carried out in this paper does not take into account road traffic. The study did not analyse the occurrence of injured persons among people travelling by roads (drivers, passengers).

The population density was calculated during the day and at night. Daytime is considered between 7:00 a.m. and 7:00 p.m. and nighttime between 7:00 p.m. and 7:00 a.m. The data used for calculations:

- the GIS layer of population density in the form of a grid with a side length of one kilometre developed on the basis of 2011 national-census data from the Central Statistical Office of Poland; the layer includes data for each square metre on the total number of population and the number of population divided into age groups: from 0 to 14 years, from 14 to 64 years and more than 64 years of age. The age division was used at the stage of estimating the average number of people assigned individually to each building. While conducting studies related to consequences of accidents involving dangerous goods, it was planned to conduct the analysis of the age structure of people staying near roads, which were injured as result of accidents in road transport involving dangerous goods.

- the GIS layer for all buildings in Poland from the topographical database (BDOT10k); the layer includes data on: the base area, the number of storeys, general function and specific functions of a building; the layer is complete for the whole country; the BDOT10k database was adopted from the Geodesic and Cartographic Documentation Centre. The abovementioned data were necessary to develop the algorithm determining the estimated population density divided into nighttime and daytime. The population density determining the average number of people, residing, staying or working in a given building depending on the division of the day, is the foundation of the consequence analysis described in this work.

The GIS layer related to population density was developed thanks to the division of buildings into groups to which an estimated percentage of population was assigned. The population division into age groups as well as daytime and nighttime was also included. The abovementioned stages were implemented as follows:

- buildings in which people live, work or stay;

- buildings divided into groups: "bedroom", workplace, leisure, places occupied by people with limited movement ability throughout the day (e.g. nurseries), places occupied by people with limited movement ability 24 hours a day (e.g. hospitals) and places of collective residence, the described division is due to information on the general function of a building; 
- for each building, the total usable area was calculated - the base area and the number of storeys were multiplied;

- on the basis of expert knowledge, a percentage share of particular age groups for a given group of buildings was assumed, taking into account the part of the day;

- taking into account the population age groups and groups of buildings, the number of population was aggregated to: squares up to one kilometre, districts and provinces;

- the total usable space of a given group of buildings was calculated and assigned accordingly to the three abovementioned layers for which the population was aggregated;

- for the layers with aggregated population, an average number of people per one square metre for individual groups of buildings was calculated; then this value was assigned to the building layer;

- in the final stage, the total usable area of each building was multiplied by the value of an average number of people per one square metre in the building layer; as a result of an average number of people staying in all buildings at nighttime and daytime was obtained.

In the current stage of the studies on developing the methodology for population density, weather conditions were not taken into account at nighttime or during daytime. This will be the subject of research and analyses to be carried out in the future.

Then, four distances that set the limits of risk zones were defined. A national road was designated as the centre of each of the abovementioned zones - a potential place of accident involving dangerous goods. Dangerous goods are divided into explosive and toxic. Table 2 shows the impact range of the released dangerous goods on people.

The average estimated range of the ERPG 2 zone for chlorine was used to determine the maximum impact range for toxic dangerous goods. The above range was calculated in the ALOHA program, used to forecast the risk zones [15]. The definition of ERPG 2 determines the occurrence of the maximum concentration of a given chemical compound in the air, below which almost all people exposed for one hour will be able to evacuate themselves and will not suffer serious health effects [16].

The division of zones was determined taking into account the emergency services experience related to removing traffic accidents and literature on determination of risk zones.

In order to calculate the level of consequences, the national roads layer was divided into sections up to one kilometre long. The consequence analysis was carried out separately for each area around the aforementioned sections of national roads. Four types of maps were developed: $S_{D W}$ - consequences of an accident involving explosive dangerous goods in the daytime, $S_{D T}$ - consequences of an accident involving toxic dangerous goods in the daytime, $S_{N W}$ - consequences of an accident involving explosive dangerous goods at nighttime, $S_{N T}$ - consequences of an accident involving toxic dangerous goods at nighttime.

The calculations of consequence levels for the above map variants were made in accordance with the following assumptions:

- the average number of people exposed to consequences of an accident for each national road section was estimated taking into account the time of day and the type of hazard posed by dangerous goods:

a) for each national road section the assigned points: $125 \mathrm{~m}, 200 \mathrm{~m}, 400 \mathrm{~m}$ and $500 \mathrm{~m}$, and buffers with the following radii: $300 \mathrm{~m}, 1 \mathrm{~km}, 2 \mathrm{~km}$ and $6 \mathrm{~km}$, respectively,

b) the number of people in each buffer for daytime and nighttime was calculated,

c) data on the population were aggregated in terms of the buffer size from point a), then the mean of 8 points, 5 points, 2.5 points and 2 points per kilometre was calculated, respectively;

Table 2 - Impact range of dangerous goods [15,16]

\begin{tabular}{|c|c|c|}
\hline \multirow{2}{*}{ Range } & \multicolumn{2}{|c|}{ Justification for the size range of risk zones connected to an accident involving: } \\
\hline & Toxic dangerous goods & Explosive dangerous goods \\
\hline $\begin{array}{c}\text { Range I } \\
\text { up to } 300 \mathrm{~m}\end{array}$ & $\begin{array}{l}\text { The average size of a risk zone determined } \\
\text { by emergency services during accidents } \\
\text { involving dangerous goods in road transport }\end{array}$ & $\begin{array}{l}\text { The occurrence of high thermal radiation (above } 10 \\
\mathrm{~kW} / \mathrm{m}^{2} \text { ) during a BLEVE and a FIREBALL of a tanker } \\
\text { carrying dangerous goods }\end{array}$ \\
\hline $\begin{array}{l}\text { Range II } \\
\text { up to } 1 \mathrm{~km}\end{array}$ & $\begin{array}{l}\text { The maximum risk zone in the case of large } \\
\text { releases }\end{array}$ & $\begin{array}{l}\text { The maximum risk zone determined by emergency services } \\
\text { in cases of accidents involving dangerous goods, during } \\
\text { which there is a BLEVE hazard and a FIREBALL hazard, } \\
\text { the zone size is related to, among other possible fragments }\end{array}$ \\
\hline $\begin{array}{l}\text { Range III } \\
\text { up to } 2 \mathrm{~km}\end{array}$ & $\begin{array}{l}\text { The zone with a radius of } 2 \mathrm{~km} \text { is connected } \\
\text { to the average risk zone for large releases } \\
\text { during the day }\end{array}$ & - \\
\hline $\begin{array}{l}\text { Range IV } \\
\text { up to } 6 \mathrm{~km}\end{array}$ & $\begin{array}{l}\text { The average estimated range of the ERPG } 2 \\
\text { zone in case of chlorine release }\end{array}$ & - \\
\hline
\end{tabular}


- the range (minimum and maximum value) of the average number of exposed people to consequences of an accident for each national road section and each range was calculated, including daytime and nighttime;

- the ranges of the aforementioned average number of people were divided according to a five-point scale; Jenks natural division was used for this purpose (Table 3).

Consequence levels $S_{D W} S_{D T}, S_{N W}, S_{N T}$ were calculated according to the formula

$$
\begin{aligned}
S= & \left(S_{6 \mathrm{~km}} \cdot W S_{6 \mathrm{~km}}\right)+\left(S_{2 \mathrm{~km}} \cdot W S_{2 k m}\right)+\left(S_{1 \mathrm{~km}} \cdot W S_{1 \mathrm{~km}}\right) \\
& +\left(S_{300 \mathrm{~m}} \cdot W S_{300 \mathrm{~m}}\right)
\end{aligned}
$$

During the calculations, the weights for individual impact zones of dangerous goods were taken into account (Table 4), the results were rounded to integers.

Weights included in Table 4 were adopted on the basis of expert knowledge and real events that occurred in the past; according to literature, the largest number of casualties occurred within 300 metres from the accident sites; taking into account accidents involving explosive dangerous goods, in case of an explosion, the largest thermal radiation occurs within a radius of 300 metres, while fragments may be thrown around at a distance of up to one kilometre; they are less dangerous than thermal radiation; the mentioned weights for impact zones of toxic dangerous goods result from the fact that in the case of an event involving them people nearest to the source of emission are most threatened (due to the highest concentration); weights for further distances are the interpolation of consequences resulting from smaller concentrations.

\subsection{Risk analysis for an accident}

The risk analysis compared the results of the likelihood analysis and the consequence analysis using the risk matrix. As a result, each section of national roads was assigned an individual risk level.

\section{RESULTS}

\subsection{Likelihood analysis for an accident}

Table 5 lists explosive and toxic dangerous goods that were most commonly involved in road accidents in the years 2010-2015. In total, there were 108 fire-service operations connected to explosive dangerous goods and 54 fire-service operations connected to toxic dangerous goods. Table 6 describes the frequency of accidents involving the abovementioned dangerous goods.

\begin{tabular}{|c|c|c|c|c|c|c|c|}
\hline & & & \multicolumn{4}{|c|}{$\begin{array}{l}\text { Average number of people living near national roads } \\
\qquad(\min -\max )\end{array}$} \\
\hline & & \multicolumn{2}{|c|}{ Buffer } & $6 \mathrm{~km}$ & $2 \mathrm{~km}$ & $1 \mathrm{~km}$ & $300 \mathrm{~m}$ \\
\hline \multicolumn{4}{|c|}{ Mean [points per km] } & 2 & 2.5 & 5 & 8 \\
\hline \multirow{2}{*}{\multicolumn{3}{|c|}{ Range of analysed data }} & Day & $8-1,026,500$ & $0-236,533$ & $0-68,674$ & $0-18,684$ \\
\hline & & & Night & $55-857,526$ & $0-147,616$ & $0-53,533$ & $0-7,042$ \\
\hline \multirow{10}{*}{ 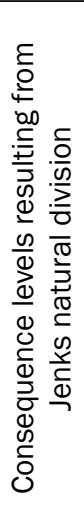 } & \multirow{2}{*}{1} & \multirow{2}{*}{$\begin{array}{l}\text { Very minor } \\
\text { consequences }\end{array}$} & Day & $8-47,836$ & $0-8,272$ & $0-2,425$ & $0-548$ \\
\hline & & & Night & $55-39,303$ & $0-5,787$ & $0-2,154$ & $0-228$ \\
\hline & \multirow{2}{*}{2} & \multirow{2}{*}{$\begin{array}{l}\text { Minor } \\
\text { consequences }\end{array}$} & Day & $47,837-151,637$ & $8,273-25,136$ & $2,426-7,537$ & $549-1,765$ \\
\hline & & & Night & $39,304-120,458$ & $5,788-16,728$ & $2,155-6,715$ & $229-824$ \\
\hline & \multirow{2}{*}{3} & \multirow{2}{*}{$\begin{array}{l}\text { Average } \\
\text { consequences }\end{array}$} & Day & $151,638-320,614$ & $25,137-54,727$ & $7,538-14,798$ & $1,766-3,502$ \\
\hline & & & Night & $120,459-244,008$ & $16,729-34,902$ & $6,716-13,279$ & $825-1,745$ \\
\hline & \multirow{2}{*}{4} & \multirow{2}{*}{$\begin{array}{l}\text { Major } \\
\text { consequences }\end{array}$} & Day & $320,615-589,472$ & $54,728-104,928$ & $14,799-25,649$ & $3,503-8,491$ \\
\hline & & & Night & $244,009-440,004$ & $34,903-65,267$ & $13,280-23,705$ & $1,746-3,061$ \\
\hline & \multirow[t]{2}{*}{5} & \multirow{2}{*}{$\begin{array}{l}\text { Very major } \\
\text { consequences }\end{array}$} & Day & $\begin{array}{l}589,472- \\
1,026,500\end{array}$ & $\begin{array}{c}104,929- \\
236,533\end{array}$ & $25,650-68,674$ & $8,492-18,684$ \\
\hline & & & Night & $440,005-857,526$ & $65,267-147,616$ & $23,706-53,533$ & $3,061-7,042$ \\
\hline
\end{tabular}

Table 3 - Summary of consequence levels depending on the population density

Table 4 - Weights for impact zones of dangerous goods

\begin{tabular}{||l|l|l|c|c|c||}
\hline \multicolumn{2}{|c|}{} & $W S_{6 \mathrm{~km}}$ & $W S_{2 \mathrm{~km}}$ & $W S_{1 \mathrm{~km}}$ & $W S_{300 \mathrm{~m}}$ \\
\hline \hline \multirow{2}{*}{ Weight for a section connected to explosion hazard } & Day $-S_{D W}$ & 0 & 0 & 0.3 & 0.7 \\
\cline { 2 - 7 } & Night $-S_{N W}$ & 0 & 0 & 0.3 & 0.7 \\
\hline \multirow{2}{*}{ Weight for a section connected to toxic vapours hazard } & Day $-S_{D T}$ & 0.12 & 0.18 & 0.28 & 0.42 \\
\cline { 2 - 7 } & Night $-S_{N T}$ & 0.15 & 0.2 & 0.3 & 0.35 \\
\hline
\end{tabular}


Madej M, Pająk M. Road Transport of Dangerous Goods in Poland - Risk Analysis

Table 5 - Dangerous goods most commonly involved in road accidents in the years 2010 - 2015

\begin{tabular}{||c|c|c|c|c|c||}
\hline UN No. & $\begin{array}{c}\text { Hazard } \\
\text { identification } \\
\text { number }\end{array}$ & $\begin{array}{c}\text { Packing } \\
\text { group }\end{array}$ & Name of dangerous goods & Hazard type & $\begin{array}{c}\text { Number of } \\
\text { operations }\end{array}$ \\
\hline \hline 2031 & 885 & $\mathrm{I}$ & Nitric acid & Toxic & 8 \\
\hline 1824 & 80 & $\mathrm{II}$ & Sodium hydroxide in solution & Toxic & 5 \\
\hline 1789 & 80 & $\mathrm{II}$ & Hydrochloric acid & Toxic & 4 \\
\hline 1791 & 80 & $\mathrm{II}$ & Hypochlorite in solution & Toxic & 4 \\
\hline 2209 & 80 & $\mathrm{III}$ & Formaldechyd & Toxic & 3 \\
\hline 2586 & 80 & $\mathrm{II}$ & Acethylicic acids & Toxic & 3 \\
\hline 1965 & 23 & - & LPG & Explosive & 51 \\
\hline 1203 & 33 & $\mathrm{II}$ & Petrol & Explosive & 23 \\
\hline 1268 & 33 & $\mathrm{I}$ & Petroleum distillations & Explosive & 3 \\
\hline 1307 & 33 & $\mathrm{II}$ & Xylenes & Explosive & 3 \\
\hline 1170 & 33 & $\mathrm{II}$ & Ethanol & Explosive & 3 \\
\hline 1173 & 33 & $\mathrm{II}$ & Ethyl acetate & Explosive & 3 \\
\hline 1972 & 223 & - & Liquefied methane & & 3 \\
\hline \hline
\end{tabular}

Table 6 - Frequency of accidents involving dangerous goods [14]

\begin{tabular}{||c|c|c|c||}
\hline $\begin{array}{c}\text { Frequency of } \\
\text { accidents involving } \\
\text { dangerous goods }\end{array}$ & Scale & $\begin{array}{c}\text { Number of accidents involving explosive } \\
\text { dangerous goods within a radius of 15 } \\
\text { km from a given national road section }\end{array}$ & $\begin{array}{c}\text { Number of accidents involving toxic } \\
\text { dangerous goods within a radius of 15 } \\
\text { km from a given national road section }\end{array}$ \\
\hline \hline 1 - very small & 0 & 0 & 0 \\
\hline 2 - small & 0.25 & 1 & 1 \\
\hline 3 - average & 0.5 & $2-3$ & 2 \\
\hline $4-$ large & 0.75 & $4-7$ & $3-4$ \\
\hline $5-$ very large & 1 & $8-9$ & $5-6$ \\
\hline
\end{tabular}

Figures 1 and 2 show the maps of the frequency of accidents involving the abovementioned dangerous goods. The frequency of emergency action connected with transporting explosive dangerous goods is the highest in the southern part of the country (Figure 1). Emergency actions connected with toxic dangerous goods took place most commonly in the southern and central parts of the country (Figure 2).

When analysing the distribution of all accidents involving dangerous goods, it should be stated that more than $55 \%$ of emergency activities took place on national roads or in their immediate vicinity.

After developing the GIS layers, Equations 1 and 2 were calculated. The results of the equations were divided into five classes which were assigned the likelihood levels for each section of national roads, up to one kilometre long. The correct division into classes occurs when the differences in values within a given class are minimized and at the same time the differences between classes are maximized. While determining the classes for the equation results, the natural division of Jenks was used, which meets the above mentioned standards. Table 7 describes the likelihood classes of an accident involving dangerous goods.
Figures 3 and 4 show the likelihood maps of an accident involving dangerous goods. In case of explosive dangerous goods, the abovementioned likelihood is the highest in northern and eastern Poland. In the case of toxic dangerous goods, an accident is most likely to occur in the south-western part of Poland.

\subsection{Consequence analysis of an accident}

Figures 5 and 6 present examples of consequence maps at night and during day.

Table 7 - Likelihood classes of an accident involving dangerous goods

\begin{tabular}{||l|c|c||}
\hline \hline \multirow{2}{*}{$\begin{array}{c}\text { Likelihood classes } \\
\text { for } 1 \mathrm{~km} \text { national } \\
\text { road section }\end{array}$} & \multicolumn{2}{|c|}{$\begin{array}{c}\text { Ranges of equation results } \\
\text { for dangerous goods }\end{array}$} \\
\cline { 2 - 3 } & Explosive (1) & Toxic (2) \\
\hline \hline 1 - Very low & $0.000-0.100$ & $0.000-0.070$ \\
\hline 2 - Low & $0.101-0.312$ & $0.071-0.280$ \\
\hline 3 - Average & $0.313-0.520$ & $0.281-0.520$ \\
\hline 4 - High & $0.521-0.608$ & $0.521-0.650$ \\
\hline 5- Very high & $0.609-0.820$ & $0.651-0.950$ \\
\hline \hline
\end{tabular}




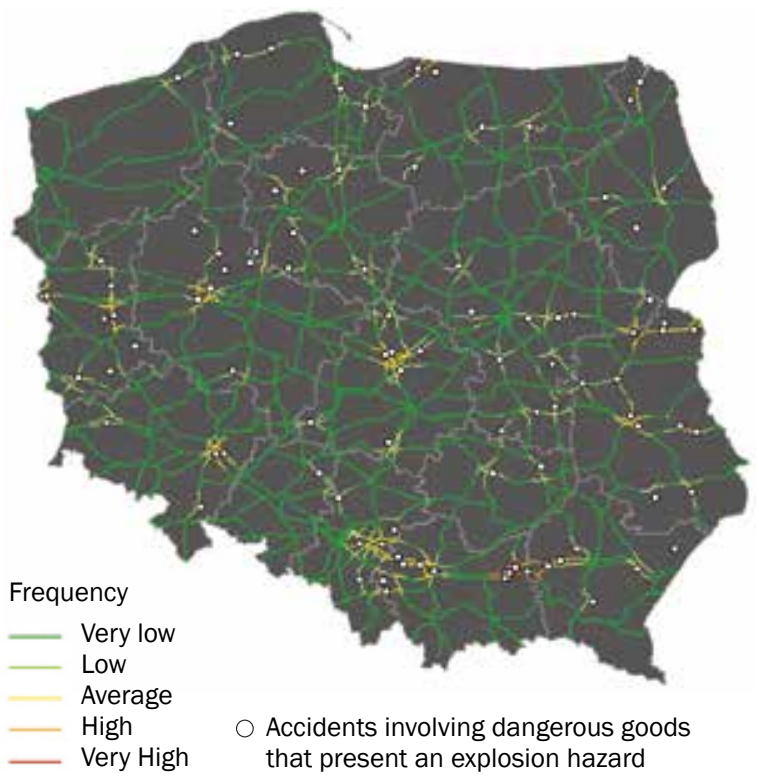

Figure 1 - Frequency of accidents involving explosive dangerous goods [14]

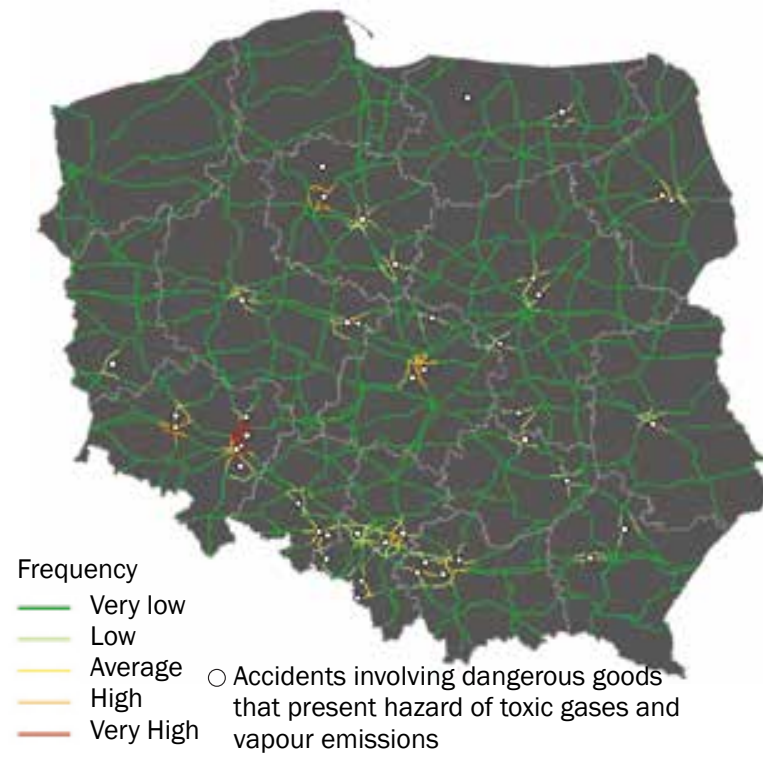

Figure 2 - Frequency of accidents involving toxic dangerous goods

It should be stated that the scale of consequences of accidents is to a large extent related to the part of the day and the type of a hazard generated by dangerous goods being transported.

\subsection{Accident risk analysis}

As a result of the comparison of two variants of the likelihood analysis $(P W, P T)$ and four variants of the consequence analysis $\left(S_{D W}, S_{D T}, S_{N W}, S_{N T}\right)$, the final risk analysis includes the following four options: $R_{D W}, R_{D T}$, $R_{N W}, R_{N T}$, where: $R_{D W}$ - the risk of an accident involving explosive dangerous goods with a hazard during day, $R_{D T}$ - the risk of an accident involving toxic dangerous

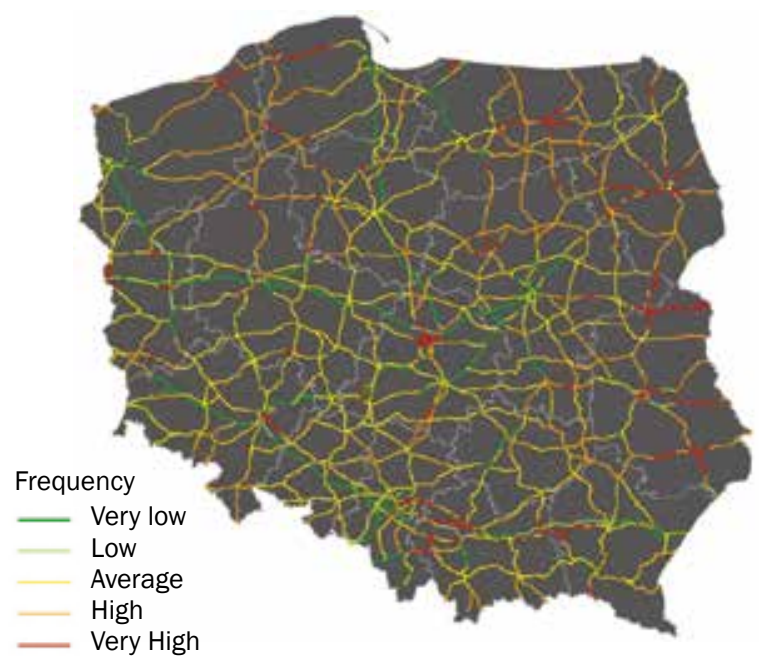

Figure 3 - Likelihood of an accident involving explosive dangerous goods

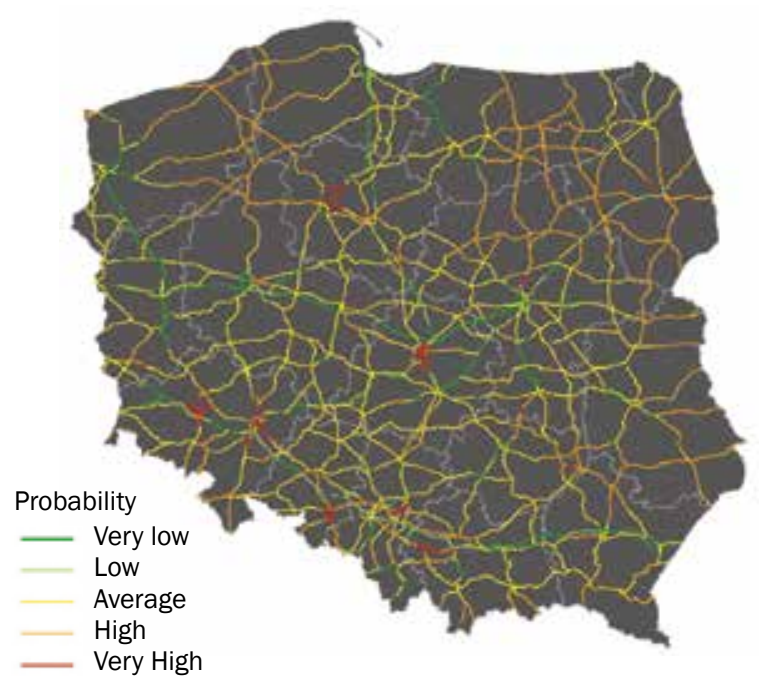

Figure 4 - Likelihood of an accident involving toxic dangerous goods

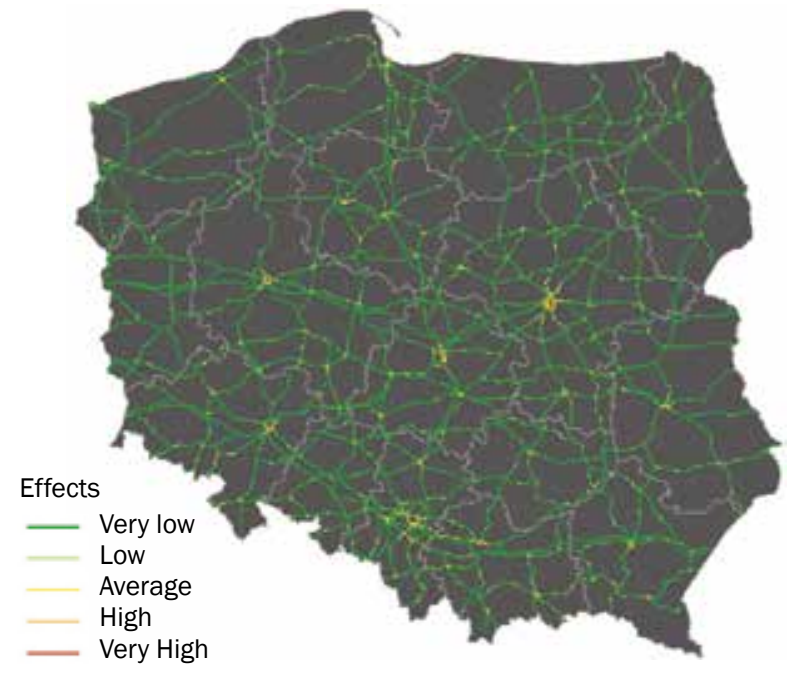

Figure 5 - Consequences of an accident involving explosive dangerous goods during day 


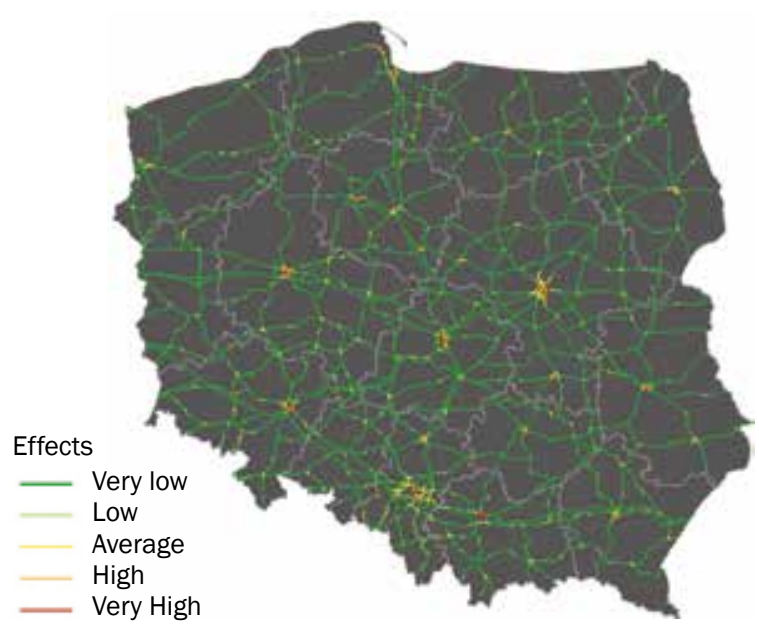

Figure 6 - Consequences of an accident involving toxic dangerous goods at night

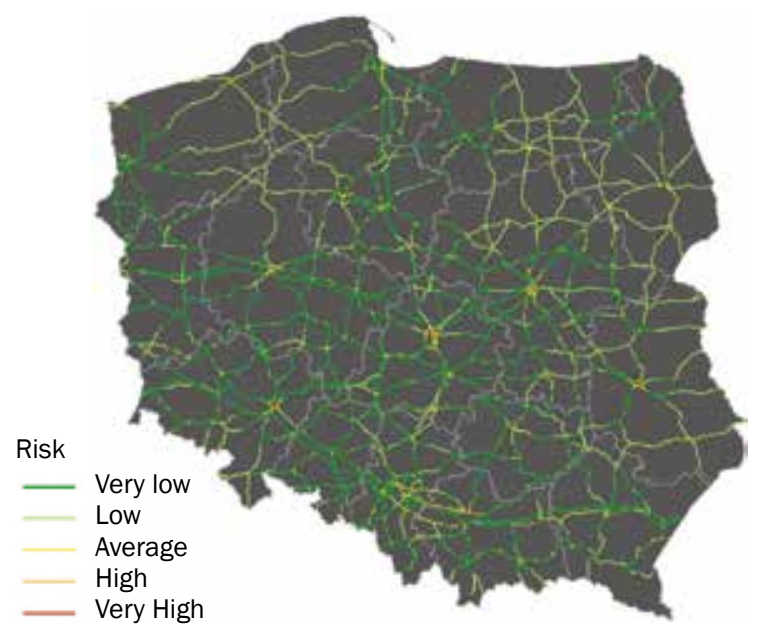

Figure 7 - Risk of an accident involving explosive dangerous goods during day

goods with a hazard during day, $R_{N W}$ - the risk of an accident involving explosive dangerous goods with a hazard at night, $R_{N T}$ - the risk of an accident involving toxic dangerous goods with a hazard at night.

The comparison of the consequence analysis and the likelihood analysis for particular risk variants was developed on a 5-point scale using the risk matrix (Table 8).

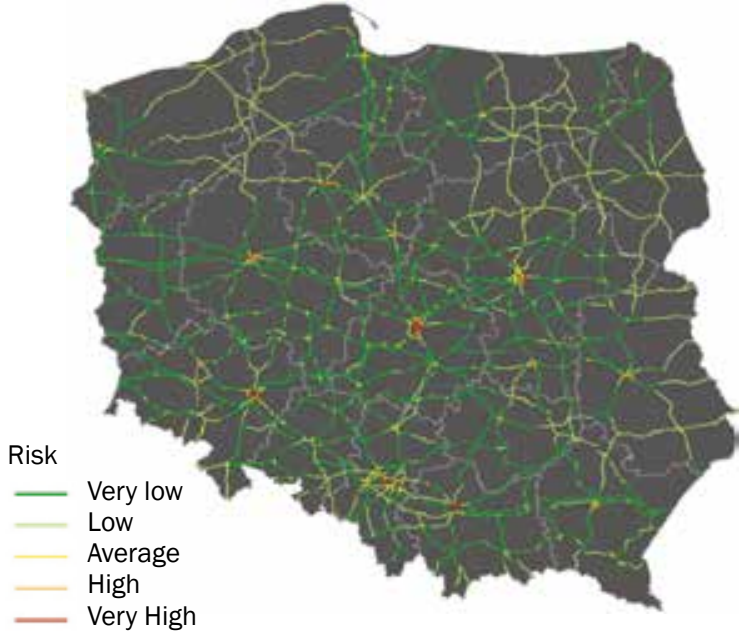

Figure 8 - Risk of an accident involving toxic dangerous goods at night

Figures 7 and 8 present examples of risk maps during daytime and nighttime.

After analysing Figures 7 and 8 , it should be stated that the risk for the same area may vary depending on the part of the day, type of dangerous goods and to the greatest extent on the population density.

\section{SUMMARY}

The possibility of assessing the risk level associated with the road transport of dangerous goods is one of the components affecting the level of public safety. The results of the work presented in this study show that the risk level may vary significantly for the same area. It is also a fact that due to the increase in the number of road transport of dangerous goods, an upward trend in accidents involving dangerous goods is noticeable.

In order to reduce the risk of hazards related to the road transport of dangerous goods, the study in this field should be continued. The aforementioned studies should also include other factors, not discussed in this paper, affecting the likelihood and consequences of accidents involving dangerous goods. Noteworthy, among others, weather conditions and road traffic conditions. They will allow for a more accurate risk analysis and thanks to that they will enable the practical use of the studies. This fits in with the world trends

Table 8 - Risk matrix

\begin{tabular}{||c|c|c|c|c|c||}
\hline 5 - Very high probability & Low risk & Average risk & High risk & Very high risk & Very high risk \\
\hline 4 - High probability & Low risk & Low risk & Average risk & High risk & Very high risk \\
\hline 3 - Average probability & Very low risk & Low risk & Average risk & High risk & Very high risk \\
\hline 2 - Low probability & Very low risk & Low risk & Low risk & Average risk & High risk \\
\hline 1 - Very low probability & Very low risk & Very low risk & Low risk & Average risk & High risk \\
\hline & $\begin{array}{c}1-\text { Very low } \\
\text { effects }\end{array}$ & $\begin{array}{c}2 \text { - Low } \\
\text { effects }\end{array}$ & $\begin{array}{c}3 \text { - Average } \\
\text { effects }\end{array}$ & 4 - High effects & $\begin{array}{c}5 \text { - Very high } \\
\text { effects }\end{array}$ \\
\hline
\end{tabular}


in which the highest level of security is becoming a priority. The abovementioned actions will be subject to future studies.

\section{CONCLUSIONS}

1) The results of the study are a valuable source of information while planning dangerous goods routes. Due to determined risk level for all sections of national roads in Poland, it is possible to implement these data when creating a network data set. It allows the development of a navigation system dedicated to road transport of dangerous goods. In the aforementioned navigation, the "cost" of a given road section would be a compilation of its travel time according to an average speed assigned to a given road type and the level of risk. The abovementioned model is analogous to a traditional navigation system, in which the traffic intensity is the equivalent of the risk level.

2) In order to optimize the risk analysis methodology, the likelihood analysis should be extended, taking into account the detailed data on road infrastructure for all national roads.

3) The risk maps mentioned in this work may be useful for the rescue services that take part in eliminating the effects of road accidents involving dangerous goods in the field of operational planning and determining priorities related to purchasing professional equipment.

MONIKA MADEJ, dr hab. inż., prof. PŚk ${ }^{1}$

E-mail: mmadej@tu.kielce.pl

MICHAŁ PAJAK, dr inż. ${ }^{2}$

E-mail: m.pajak.poczta@interia.pl

${ }^{1}$ Wydział Mecahtroniki i Budowy Maszyn

Politechnika Świętokrzyska w Kielcach

Al. 1000-lecia P.P. 7 25-314 Kielce, Polska

2 Komenda Wojewódzka PSP w Kielcach

ul. Sandomierska 81, 25-324 Kielce, Polska

\section{TRANSPORT DROGOWY TOWARÓW NIEBEZPIECZNYCH W POLSCE - ANALIZA RYZYKA}

\section{ABSTRAKT}

W pracy przedstawiono metodykę związaną z analizą ryzyka dla transportu drogowego towarów niebezpiecznych. W analizie ryzyka uwzględniono ryzyko grupowe, które dotyczy społeczeństwa zamieszkującego lub przebywającego w promieniu $6 \mathrm{~km}$ od wszystkich dróg krajowych w Polsce. Analiza została wykonana w oprogramowaniu GIS. Przygotowano matrycę uwzględniającą iloczyn prawdopodobieństwa wystąpienia wypadku w transporcie drogowym z udziałem towarów niebezpiecznych oraz skutków dla społeczeństwa zamieszkującego w wyżej wymienionym obszarze. Analizę prawdopodobieństwa opracowano dla towarów niebezpiecznych stwarzających zagrożenie: wybuchem oraz związane $z$ emisją toksycznych/trujących par. W opracowaniu analiza skutków wykorzystano gęstości zaludnienia, zgodnie z którą do każdego budynku przypisano indywidualną liczbę osób w zależności od pory doby (dzień, noc). Każdy etap analizy został zwizualizowany $w$ formie mapy. Łącznie opracowano 2 warianty analizy prawdopodobieństwa, 4 warianty analizy skutków i 4 warianty analizy ryzyka. Wszystkie analiz zostały opracowane dla obszaru całego kraju.

\section{SŁOWA KLUCZOWE}

transport; towary niebezpieczne; analiza ryzyka; gęstość zaludnienia;

\section{REFERENCES}

[1] Jamróz K, Kustra W, Wachnicka J, Berkowski M. Metodologia klasyfikacji ryzyka dla wybranych rodzajów wypadków drogowych na drogach wojewódzkich oraz dla obszarów województw i powiatów wraz z dokonaniem klasyfikacji i przedstawieniem wyników na mapach Etap I. Warszawa/Gdańsk: Ministerstwo Infrastruktury i rozwoju; 2015.

[2] Szymanek A. Rozwój standardów zarządzania ryzykiem w transporcie drogowym. Logistyka. 2014;3: 6185-6191.

[3] Norma PN-ISO 31000:2012. Zarzadzanie ryzykiem - Zasady i wytyczne. Available from: https://www. iso.org.pl/uslugi-zarzadzania/wdrazanie-systemow/ zarzadzanie-ryzykiem/iso-31000/

[4] CeON Repository. Rekomendacje formalno-prawne $z$ zakresu zarządzania kryzysowego. CNBOP-PIB; 2015, p. 138. Available from: https://depot.ceon.pl/handle/123456789/8012

[5] http://appsso.eurostat.ec.europa.eu/nui/show.do?dataset=road_go_ta_dg\&lang=en [Accessed 8 Feb. 2019].

[6] Bęczkowska S, Grabałek S, Choromański W. Model oceny ryzyka w drogowym transporcie towarów niebezpiecznych - wybrane zagadnienia. Transport. 2013; 96: 77-86.

[7] Bęczkowska S, Grabałek I. Zastosowanie technik heurystycznych w modelowaniu czynnika ludzkiego w drogowym transporcie towarów niebezpiecznych. Logistyka. 2014;4: 1655-1664.

[8] Conca A, Ridella C, Sapori E. A risk assessment for road transportation of dangerous goods: A routing solution. Transportation Research Procedia. 2016;14: 2890-2899.

[9] Banabakova V, Minevski I. Problems and risk management options for the transport of dangerous goods. Globalization, the State and the Individual. 2017;14(2): 215-222.

[10] Jamroz K, Michalski L, Budzyński M, Kustra W. Oparte na ryzyku metody zarzadzania bezpieczeństwem infrastruktury drogowej. Materiały z Międzynarodowego Kongresu Zwiększenie potencjału na rzecz bezpieczeństwa ruchu drogowego; 2013.

[11] Barcik J, Czech P. Wpływ infrastruktury drogowej na bezpieczeństwo ruchu, cz. I i Il. Transport. 2010;69.

[12] Drozdowska K. Stan infrastruktury drogowej, a bezpieczeństwo ruchu na przykładzie województwa opolskiego, Autobusy. Technika, Eksploatacja, Systemy Transportowe. 2013;3: 1489-1496.

[13] Kustra W, Jamróz K. Analysis of Factors Influencing the Density of Fatalities on National Roads in Poland. Journal of KONBiN. 2010;13(3): 221-234. Available from: 
doi:10.2478/v10040-008-0150-3

[14] Pająk M, Madej M, Ozimina D. Risk Analysis for Transport of Explosive Dangerous Goods. BiTP. 2017;48(4): 54-69.

[15] https://www.epa.gov/cameo/aloha-software [Accessed
8 Feb. 2019].

[16] http://response.restoration.noaa.gov/oil-and-chemical-spills/chemical-spills/resources/emergency-response-planning-guidelines-erpgs.html [Accessed 8 Feb. 2019] 